This item was submitted to Loughborough's Research Repository by the author.

Items in Figshare are protected by copyright, with all rights reserved, unless otherwise indicated.

\title{
The probation career of Al Truism
}

PLEASE CITE THE PUBLISHED VERSION

PUBLISHER

(c) Blackwell

LICENCE

CC BY-NC-ND 4.0

REPOSITORY RECORD

Pease, Ken. 2019. "The Probation Career of Al Truism”. figshare. https://hdl.handle.net/2134/932. 


\title{
The Probation Career of Al Truism ${ }^{1}$
}

\author{
KEN PEASE \\ Professor of Criminology, Huddersfield University
}

Abstract: The writing of Bill McWilliams on probation history and practice is briefly reviewed. Bill's plea for a theoretical moral underpinning for practice would, if answered, make the service less vulnerable to the discrediting of its claims that probation is effective in increasing public protection. These claims are ill-founded, and are only sustainable because of political and criminological disinclination to address the evidence or live with its consequences. The search for a moral underpinning might have led Bill to link probation with current concerns to combat social exclusion. This would involve detailed consideration of the distributive justice-retributive justice nexus and its implications for probation practice. It is argued that concern altruistically to give help to all those damaged by the criminal justice process, victims, witnesses, perpetrators and their families alike, would accord with a secularised but morally grounded version of the police court mission.

Altruism is defined in Chambers Dictionary as the principle of living and acting for others. The career of altruism can be considered in relation to the individual probation practitioner and the probation service, albeit in different ways. The purpose of this paper is to rehearse some of the ideas of the late Bill McWilliams, to suggest their continuing relevance to probation, and to argue how his thinking might have developed had his active life been longer. Altruism in its appeal to selflessness, and its lack of discrimination between the categories of other to be served, offers a reasonable organising principle in probation, of which Bill would have approved, and which will be elaborated somewhat in the final section of the paper.

The late Victorian ancestor of the probation officer was the police court missionary. The first missionaries were employees of the Church of England Temperance Society. As Bill McWilliams (1983) stressed:

The missionaries had a religious philosophy, distinctively their own, and when they first entered the summary courts their transcendent task was the saving of souls through divine grace. (p. 130)

Their task was the restoration and reclamation of individual drunkards appearing before the criminal courts. (p. 134)

This role was compromised by magistrates' use of missionaries to supervise offenders released on recognizances under the provisions of the Summary Jurisdiction Act 1879. The next step was the use of missionaries to undertake pre-sentence reports. Bill (1983) quoted the annual report of the London Police Court Mission for 1889 as follows:

the missionaries are at the court for some time before the magistrate takes his seat on 
the Bench, and during this time they make acquaintance ... with those that are about to be charged. Then, as each prisoner attends in the dock, the missionary being in his place in the court, the magistrate will constantly ask what may be done for this or that case. (p. 137)

The missionary ideal fell, Bill thought, because of the doctrine of the stumbling block, namely that intemperance was the obstacle to salvation, whose removal was a pre-condition of salvation becoming possible. Coercion, under this view, became a legitimate means of removing the impediment, just as the Inquisition regarded even torture as a legitimate means of saving souls. The missionary Thomas Holmes (1908) was cited by Bill as contending in 1980 that inebriate women be dealt with as follows:

If we had any thought for the purity of our streets, any concern for public morality and public decency ... we should take these women aside and keep them aside-not for one, two to three years, but for the remainder of their natural lives, justified in the knowledge that they are not responsible creatures, and that pity itself demands their submission to kindly control and strong-handed restraint. (p. 142)

The route through which the missionary ideal was discarded involved the Departmental Committee on the Social Services in the Courts of Summary Jurisdiction (Home Office 1936). This contended that the practice of social work had become more scientific:

Many of the older officers were drawn into the service by a simple desire to help others at a time when it offered the most meagre material rewards, and their missionary zeal and force of personality often compensated for their lack of technical equipment. But the range of the probation officer's duties has widened, and the technique of their work has become more scientific ... few or none of the older officers have had the training which is required in modern social work. (para. 164)

The early years of the century saw the emergence of professional aspirations in probation (McWilliams 1985). Officers began to call for training. In parallel with professional aspirations, the question of who should be placed under supervision assumed prominence. The issue of selection had been put on a new footing by the Probation of Offenders Act 1907. Mercy to the offender had been its own justification. Improvement required the choice of more tractable offenders. This change led to a shift in what probation officers were charged to tell the court. A Departmental Committee of 1910 (Parliamentary Debates 1910) asserted that:

preliminary inquiries as to the character and surroundings of the person charged ... [was] a useful practice. It enabled information to be supplied to the court ... by an officer whose duties should lead him to put as favourable a complexion on the circumstances as the facts will allow. (para. 36)

The Departmental Committee on the Training, Appointment and Payment of Probation Officers in 1922 still saw 'a keen missionary spirit' (Home Office 1922a, p. 13) as essential. By 1927, a Departmental Committee on the Treatment of Young Offenders took the view that 'a University education is ... desirable if the best results are to be obtained' (Home Office 1922b, p. 59).

Bill McWilliams saw the claim of diagnostic skill as the sine qua non of the 
probation officer's emergent professional status, and described the seemingly inexorable rise of both probation officer training as professionals and their claim accurately to identify offenders likely to be susceptible to change through probation supervision. Bill contended that what was lacking was:

a body of theoretical and empirical knowledge, accessible to the officer, which would guide the selection of the [diagnostic] facts and order their significance. (McWilliams 1985, p. 267)

The vestigial control exercised by missionary societies over probation practice ended in the late 1930s. Between then and the 1960s:

the probation system in England was transformed from a service devoted to the saving of souls through divine grace to an agency concerned with the scientific assessment and treatment of offenders. (McWilliams 1986, p. 241)

The body of theoretical and empirical knowledge which thereafter came to underpin probation practice was that of social casework. Bill (1986) traced its origins back to 'scientific charity' as practised in late Victorian England by the Charity Organisation Society, whereby the help offered to individual supplicants for charity would depend on an assessment of their situation, personality, and capacity to benefit from it. Bill saw the method crossing the Atlantic, first westward, then making the return journey as casework based on 'social diagnosis'. The mixture became headier with the addition of elements of Freudian psychology, which has always had the singular advantage of its claim that the patient/offender remains unconscious of the drivers of his or her behaviour, and is thus denied the insights on the basis of which treatment is prescribed. By this means, the diagnostician's competence does not come under challenge when the person diagnosed-or for that matter, anyone else who has not shared the analytic process-disputes it.

The touchstone against which diagnosis-driven casework must be assessed is the achievement of change in those dealt with. The 1970s saw the emergence of scepticism about this, and, Bill wrote in 1986:

the edifice of diagnostic and treatment thinking within the probation service is beginning to crumble. (p. 258)

The final phase which Bill identified in probation history was that of pragmatism (McWilliams 1987). The features of that phase are its diversity of operation, its attempt to reduce the use of custody, and the framework of policy within which probation must be practised. Although Bill identified three sub-types of the pragmatist school, (which he termed the managerial, radical and personalist) one of these, the managerial was the most influential and became still more so in the years after Bill completed his last work. As to the managerial school, Bill wrote:

... I think we may take it as inevitable that their understanding of the offender is that of a unit to be processed within a framework of policy. (p. 111)

He noted that the important Morison Committee of 1962, which conducted a uniquely extensive review of probation, made no mention of management in its report. Bill contended that the managerial ethos only flourished when 
scepticism about the effectiveness of diagnosis and treatment was called into question. He saw the key to the managerial school as follows:

' $[\mathrm{I}] \mathrm{t}$ is the managers who define the policies and the objectives, and as a consequence ... the members of the management school have come to believe that they have now taken the role of the probation service in propria persona which, in the old probation service, was held by the probation officers' (McWilliams 1981 p. 108).

Bill charted the growth of this mode of thought by reference to the increasing proportion of the service occupied by management grades, and the ever more distant relationship between the courts and the probation officers serving them (McWilliams 1981).

To summarise, Bill described the main strands in probation thinking as being from special pleading, through diagnosis to managerial pragmatism. The view of the offender which underpinned these were respectively as: a unique individual in God's sight, a unique collection of psycho-social attributes, and as a unit for policy processing. The justifying knowledge framework was respectively faith, psychology and management science. The justification for action was moral, then factual, then efficiency-driven. The means through which the aim was to be achieved was respectively moral reform, scientific treatment, and social control. This was operationalised in court as, respectively, a plea for mercy, a diagnosis and associated treatment plan, and finally the specification of a realistic disposal within the overarching policy aim of reducing the use of custody.

Why was Bill's perspective on probation history influential and compelling to many people? First, it was based on impressive scholarship. Second, it resonated with the ambivalence which many experienced probation officers felt about the development of their service, and where it rubbed uncomfortably against the personal values which had led them into probation work. Finally, it was palpably the work of someone who cared passionately for the service of which he wrote. As Mike Nellis (1997) pointed out in his Howard Journal obituary, Bill was at heart a police court missionary:

but never in a naive or nostalgic sense; he simply insisted that the Service, as it turned to face new challenges, should not discard the moral and spiritual traditions on which it had originally drawn. (p. 226)

The last words of the last paper in his quartet on probation history (McWilliams 1987) made the point well:

The passage of the Summary Jurisdiction Act 1879 produced from one member of the public the acid question 'is it fair to the law-abiding subjects of this realm that criminals should be allowed their liberty for the purpose of enabling the Government to present a favourable balance sheet of the cost of their prisons?' ... In transcendental terms that critic's answer came to be provided by the police court missionaries. In a modern context the question is being reiterated; the problem for the probation service appears to be the production of an equally justifying response. (p. 116)

\section{The Vulnerability of Current Probation Justifications}

To sustain its claim to be an efficient means of processing offenders, the probation service requires the demonstration that treatment by community 
sanctions is at worst not criminogenic relative to custody. Yet this can only be demonstrated by methodological sleight of hand. Imagine a factory which spews out noxious fumes. There is conflict about whether it is better to:

(i) close the factory down temporarily as punishment, or

(ii) allow it to continue operation, but to require its executives to undergo re-education in their environmental obligations.

An evaluative study, allocating delinquent businesses randomly to the two treatments, might compare levels of pollution caused by the businesses over two years. The two treatments, let us say, yield equal levels of pollution, but re-education is cheaper. The matter is settled. Re-education is the better option. No-one notices that the two years at risk for the closure option begins only when the factory re-opens, whereas the two years for the reeducation option begins at once. Thus clean air during the six months of closure is factored out of the comparison. Most of us would be unhappy with such an evaluation. We would want to compare like with like: emissions from the point of sanction. We would suspect that the study had been rigged so that the cheaper option seemed as good as the more expensive. Yet the example precisely mirrors what happens when custodial penalties are compared with alternatives to them.

What gets counted in penal effectiveness seems odd (or worse) relative to the real world of public protection. Measures of reconviction are conventionally used as indicators of the relative success of different penal sanctions. These measures are typically of the proportion of those given different sanctions (prison, probation and so on) who are reconvicted within a two-year risk period, that is, two years at liberty. When reconviction rates are compared in this way, the differences between sanctions are typically slight. However, what this neglects is the point at which the risk period starts. For probation, it is immediate. For those given custodial sentences, it only starts after release from custody. Let us take a group serving a one year prison sentence $^{2}$, and another given probation orders. One year after sentence, many of those given probation will have been reconvicted. One year after sentence, effectively none of those serving a year's imprisonment will have been reconvicted. Two years after sentence, even more of those on probation will have been reconvicted. Of the former prisoners, about as many will have been reconvicted as probationers the year before. In short, two years from sentence, fewer prisoners than probationers will have been reconvicted, simply because they were locked up for part of the time. By comparing two year periods at liberty, the effect of prison in keeping people from committing offences is ignored, giving probation a massive advantage. The statistics as presented look as though probation is as good as prison in conferring public protection simply because reconvictions only start being counted after the incapacitation effect of prison has done its bit. The comparison should be from the point of sentence, that is, that two year reconviction rates for probation should be calculated from the same point as two year conviction rates for imprisonment, dating from sentence. Only thus is relative public protection clear. Why is this not done? 
(i) Because of cost and sentiments of mercy, there is a continuing wish to reduce the use of custody. To clarify its advantage in public protection would not be regarded as helpful.

(ii) The extent of measured effectiveness required would demoralise the probation service.

Many factors determine risk of reconviction. Most are knowable at the point of sentence. They include age at first offence, offence type and gender. Direct comparison of those given, for example, community service and those given custody will show an apparent superiority for the less intrusive sentence, simply because those assigned to it are less criminal. Respectable studies statistically factor out such variables to yield a pure comparison. A Home Office study (Lloyd et al. 1994) did this for prison and community penalties. The results are simplified as Table 1. This shows that the proportion of people reconvicted after two years is almost exactly as could have been predicted before sentence on the basis of age, gender and criminal history. It is no worse than expected after custody and no better than expected after community sentences. No sentence achieves overall more than a trivial effect on reconviction. Furthermore, these figures relate to two years at risk, that is, they take no account of the protective effect of custody. What is more, while they factor out those convictions which occur during the course of a penalty but which relate to offences committed before the sanction, they do not factor out convictions which occur after the risk period but which relate to offences committed during the course of the penalty. Since the scope for such convictions is much greater for community penalties than for custody, the effect of this is to make community penalties look better relative to custody than they merit.

What do these figures mean in terms of public protection? What follows is an illustrative exercise ${ }^{3}$. To fully address all the technical niceties (see Blumstein et al. 1986; Tarling 1993 for technical discussions) would require a major research and analytic exercise. However the illustration is adequate to show the order of magnitude of the net effects of the sanctions.

Incorporating the incapacitation effect means that, after any time period, the proportion of those reconvicted after a custodial sentence is lower than the proportion reconvicted after a community sentence, given that the effect of sentence is vanishingly small in both cases. The difference becomes

TABLE 1

Two Year Reconviction Rates by Sentence (modified from Lloyd et al. 1994)

\begin{tabular}{lccc}
\hline $\begin{array}{l}\text { Sentence } \\
\text { Group }\end{array}$ & $\begin{array}{c}\% \\
\text { Reconvicted }\end{array}$ & $\begin{array}{c}\% \\
\text { Predicted }\end{array}$ & Number \\
\hline Prison & 54 & 53 & 9615 \\
Community penalties & 47 & 49 & 8196 \\
Probation & 43 & 45 & 2448 \\
Community service & 49 & 52 & 2394 \\
\hline
\end{tabular}


FIGURE 1

Cumulative Reconviction Rates

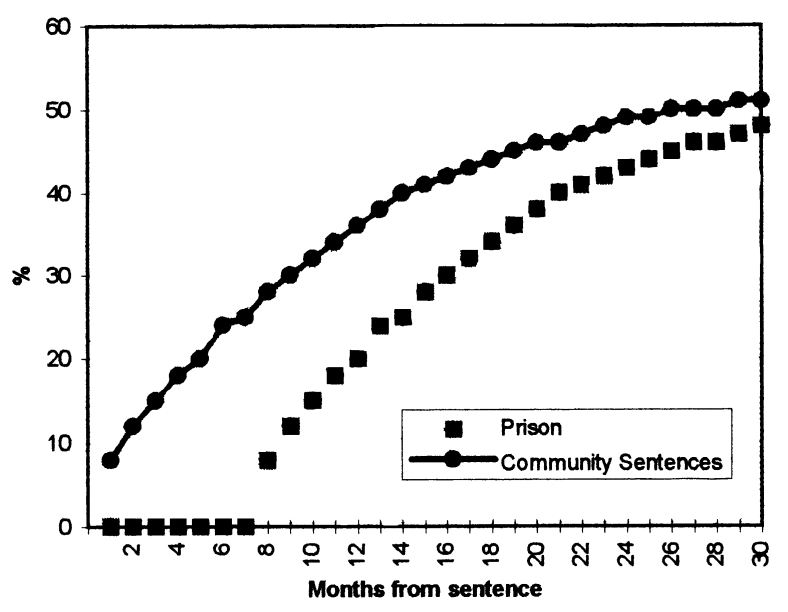

smaller as time goes on, but the curves will not cross, so that at every time period some slight protection is conferred by custody in the past. By the time a prisoner having served an average sentence length is released, some $28 \%$ of those given a community sentence will have offended again, at least once.

The reality of the comparison is more complex. Revictimisation of victims and witnesses by proxy, by friends and family of a prisoner, is more common than we might wish. However, saying that people will be victimised by proxy scarcely seems a valid reason for avoiding custody for the original perpetrator. One feature of criminal careers which would negate this argument is to say that time spent in custody lengthens a criminal career, that is, that a criminal career lasts a fixed number of free years, with custody serving only to lengthen that period. This does not make intuitive sense. Nor is there any research evidence in support of the notion.

Motivated offenders can change, and reviews of the literature suggest that some programmes can produce measurable results (see for example McGuire 1995; Hedderman et al. 1997). If the policy lesson taken from this paper is that a quantum leap in the provision, competence and funding of change programmes is necessary, so be it. Any defensible benchmark comparison with custody leaves community sanctions a lot further behind in terms of public protection than has typically been acknowledged.

Another tactic which has been used to promote alternatives to custody has been the attempt to shame Britain by representing it as almost uniquely punitive. Cross-national comparisons of prison population typically place the UK at or near the top of the league of number of prisoners per $100 \mathrm{k}$ population. The mental leap is then made to the conclusion that the UK is punitive. This is like saying that the higher the number of people in hospital, the more caring the society. The amount of disease may in large part determine the number of people in hospital. Likewise, the amount of crime 
and the activity of the criminal justice agencies may have something to do with the number of people in prison. Looking at the prison population per conviction places England and Wales among the least punitive countries in respect of rape, robbery, assaultive crime, theft and fraud (see Pease 1994). Shame induced by the assertion that we are given to punitiveness is almost certainly misconceived.

In short, reliance on efficiency and cost arguments will pay dividends only so long as people do not notice the methodological shortcomings of the relevant comparisons. They may not notice for some time, but one should sleep easily once one has recognised the problem. The purpose here is not to decry the work of the probation service, any more than that was the intention of Bill McWilliams's critiques of the service, but rather to reassert Bill's point that the original justification for the police court missionary was a moral one, and the moral force of the aim to help remains the primary one. If one moves from this to a more utilitarian conception of appropriate sentencing, one is on difficult ground indeed, reliant on criminologists not to mention the probation Emperor's nakedness, and on politicians to place economic considerations before public protection ${ }^{4}$.

\section{What Might Yet Be}

While Bill was deeply engrossed in historical study, he was also exercised by how things might develop, or might have developed. Some of the greatest fun we had when writing together was the construction of cameos about how community service might change and be changed by its immersion within probation culture (Pease and McWilliams 1976). He was willing to be playful, and allow himself to seem ridiculous as time passed. Because of this, if professionally active now, I think Bill would be interested in what has come to be known as counterfactual history. This is the informed speculation about how history might have played itself out if decisions had been made differently or events had turned out differently. For example, had John F. Kennedy not been assassinated, it is very possible that the Vietnam war would have been prolonged, and the civil rights movement in the USA much delayed and bloodier (Kunz 1997). If Charles I had invaded Scotland in June 1639, as his advisers urged, it is likely that the Stuart line would have survived for at least another century and the nature of British parliamentary democracy now would have been profoundly different (Adamson 1997). While some historians regard counterfactual history as frivolous (for example, Carr 1987), it has virtues which would have appealed to Bill, and indeed there are some echoes of counterfactual history in what Bill and others wrote. The virtues of counterfactual history include (see Ferguson 1997):

(i) History is typically written by the victor. This tends to give the impression that it was somehow a desirable or inevitable outcome. Bill's account of the history of the probation service is unusual in that it is history written by the vanquished. ${ }^{5}$

(ii) History as written is not the same as history as lived. For instance, the fears and uncertainties of the Second World War tend to disappear with hindsight. Dorothy Bochel (1976) shows that the transition from police court missionary to probation officer was far from the simple assumption of the former's mantle by the latter, the 
professions were concerned with similar professional turf, as "the fierce struggles which took place in the 1920s and 1930s between those favouring a "professional" development and the increasingly desperate rearguard actions of the mission societies' testify (Bottoms 1977).

The reason Bill would have been interested in virtual history would be the sense that one historical outcome does not extinguish the strands of thought temporarily defeated. The velvet revolution in the former USSR did not extinguish Leninist thought or Leninist thinkers, and at the time of writing it seems that their days of power may return. There remain in probation strands of missionary thinking. The understandings offered by a virtual history of probation would allow the recognition of how police court missionary thinking may have developed, and hence how those strands could be stressed in prescriptions for modern probation practice which would revive missionary zeal. If Bill could understand, by study of counterfactual history, the mental routes traversed by those temporarily vanquished, perhaps he could help to direct them into the mainstream again. If he could understand recent real history, perhaps he could use it as a trout-fisher uses a fly, to induce something present but submerged to re-emerge.

\section{The Route of the Vanquished Missionary}

What would the probation service have been like had the missionary ideal not been overtaken by the pseudo-science of casework? The central purpose of the missionary's work was communicating social disapproval ${ }^{6}$, and reconciliation with God:

Because of the Mission's vision of salvation, the relationship between offender, missionary and sentencer was not, in fact, that which is usually portrayed in which the supplicant offender was the recipient of the altruistic pleading of the missionary and the mercy of the sentencer. Rather, ... the relationship was one of reciprocity; each of the parties gave, but also received. The offender gave an earnest of reform and received the plea of the missionary, the mercy of the sentencer, and the opportunity to repent and be saved. The missionary gave a pledge to look after and to supervise the offender in pursuit of his reformation and received an enhancement of grace; and the sentencer gave mercy and, like the missionary, received an enhancement of grace also. (McWilliams 1983, p. 140)

Bill was enough of a realist to recognise that religious faith was no longer a plausible driver of probation principle. Neither was he slow to suggest what the secular descendant of the police court missionary would do, the "what if' of the missionary spirit translated into the mid-20th century. The essence of this is contained in the highly influential 'Non-treatment paradigm for probation practice', which he published with Tony Bottoms in 1979). It is a clever approach, sufficiently similar to contemporary managerial concerns as not to be dismissed out of hand, but placing help at the centre of the relationship between supervisor and person supervised. Aim 1 of the approach is the provision of appropriate help for offenders. This is explicitly linked to the style of the police court missionary:

The original practice of the early probation service was probably to stress, in particular, advice and practical assistance. With the context of a strongly moralistic relationship, 
the offender was steered into better paths by exhortation, the arrangement of employment, and so on. (Bottoms and McWilliams 1979, p. 169)

In the Bottoms and McWilliams approach, treatment became help, diagnosis became shared assessment, and the client's dependent need became a collaboratively defined task as the basis for social work action. Bill remained centrally concerned with the justification for giving such help. In a joint paper with the writer of this article, Bill contended that:

The cost-effective-cum-humanitarian justifications put forward for the present policy of 'alternatives' lack the cachet, and indeed the rectitude, of earlier claims to save souls or to change psyches. Lack of over-arching purpose makes probation particularly vulnerable to political pressure. The probation service's response to overt and covert attack over the last decade has been conceptually spineless, and in consequence unpersuasive. The probation service stands in need of a transcendent justification for its activities. (McWilliams and Pease 1990, p. 16)

Bill thought he had found a route to the answer in the philosopher Alan Gewirth's (1978) Principle of Generic Consistency. This is too complex to describe here, but the lesson which Bill drew from it was that the purpose of punishment was to restore membership in the community by an offender's unforced choice, a theme consistent with recent emphases on restorative justice.

The central advantage of such a perspective is that it does not neglect distributive justice while considering punishment, contending that distributive justice must be departed from only in such a way as to reinstate an equality which has been disrupted. In short, Bill would have seen:

- a central concern for distributive justice

- the provision of help

as the themes to which the police court missionary would resonate, and which are of sufficient contemporary interest to fuel a resurrection of missionary thinking. Since first writing the above, I have read Cheetham's (1998) 'Crime, probation and social work: enduring rights and wrongs', which is consistent with the Bottoms and McWilliams approach, with some developments.

\section{Lures for Missionary Thinking to Resurface}

If a concern for distributive justice and the provision of help were the modern concerns of the reborn and secular police court missionary, what are the issues which would act as lures to induce the missionary part of most officers to resurface? In more modern terms, what the court missionary addressed was social exclusion. For this reason, Bill found Antony Duff's (1986) stress on communication as the substance of punishment attractive. Social exclusion was cast in religious terms by the missionaries. The government has now established a Social Exclusion Unit within the Cabinet Office. Social exclusion is distinguished from poverty and inequality by Katherine Duffy (1998) as follows:

... exclusion has the meaning of being expelled from a place where you stood before, 
and of being kept outside by denial of access. Generally, the distinction made between poverty and social exclusion, is that between a focus on inadequate or unequal material resources, vis a vis inadequate or unequal participation in social life. (p. 228)

The end of punishment to which Bill referred was precisely the end of social exclusion. Social exclusion as it concerns offenders is located at the nexus of distributive and retributive justice. Retributive justice concerns the restoration of the balance of effort and advantage between an offender and society. Distributive justice concerns the range and limiting conditions which humans should be allowed to experience, notably as regards pain and poverty. It is the intersection between these where the most pressing problems of probation and other penal sanctions lie. At the crudest level, what is the justification of 'goodies for baddies', like driver training for motoring offenders and after-care for prisoners? The justification cannot lie in retribution. It must concern the restoration of the state of citizenship which would have applied in the absence of the penalty, or at least a state which does not hamper the resumption of citizenship. Difficult questions arise about distributive justice as it applies to the families of prisoners, and to those whose previous life has so damaged them that they will never resume citizenship in any meaningful way. Does distributive justice allow goodies for baddies to restore a state which never existed before, and where many will believe that it never existed because of the offender's badness? ${ }^{7}$ In any event, the social concerns of the missionary societies were about exclusion (including exclusion from a state of grace), and recent concerns with social exclusion provide a means for the revival of police court missionary thought.

Were Bill professionally active now, I believe he would be examining the literature on social exclusion, and seeking to apply Gewirth's principle of generic consistency to the special issues which it raises for the exclusion of offenders. He would be working at the points where distributive and retributive justice rub against each other in probation practice.

The second lure inducing missionary thinking to resurface is the contemporary role of the victim movement. The work of the police court mission took the missionary to many places. Bill (1983, p. 135), citing Thompson (1884) and 'a Middlesex magistrate' (1911) stressed that:

[t] he missionaries made themselves generally useful to the magistrates by acting in matrimonial disputes, neighbours' quarrels, children beyond their parents' control, assessing applicants for the poor box, and so on.

One missionary in the year $1877 / 78$ visited courts, prisons, fire and railway stations, and cab stands. Visits to cab stands outnumbered visits to court by more than two to one. Joan King (1958) confirms that missionary duties included 'matrimonial conciliation, prison after-care and work with children who had not committed offences' (p.5). They were also required to devote time to the general work of their missions (p. 7). It was pressure from courts which led to the increase of missionary involvement therein, not the demands of the vocation. In other words, missionary work took its exponent to wherever useful work was to be done. The 'appropriate help' aim given 
primacy in the non-treatment paradigm is not necessarily limited to the offender.

Institutional concern with offenders pre-dated institutional concern with victims. Obviously this is not to say that sympathy for and charity to victims of crime was not evident before. Dickens was apparently often moved to tears by the centrepiece of his one-man show, the story of Nancy's murder by Bill Sikes. In fact, sympathy for victims was a major and increasing motif of the Dickens genre (Collins 1994). The Forfeiture Act of 1870 reintroduced the principle of compensation for victims. The secretary of the Howard Association, William Tallack, wrote on restitution (see Wright 1982). The victim movement, however, is a product of the mid-20th century, and the attempt to reclaim offenders was active a century earlier. An interesting illustration of the thinking of the intervening period comes in the remarks of Winston Churchill (Parliamentary Debates 1910), often quoted for the nobility of the sentiment expressed:

The mood and temper of the public in regard to the treatment of crime and criminals is one of the unfailing tests of any country. A calm, dispassionate recognition of the rights of the accused, and even of the convicted criminal, against the state-a constant heartsearching by all charged with the duty of punishment-a desire and eagerness to rehabilitate in the world of industry those who have paid their due in the hard coinage of punishment: tireless efforts towards the discovery of curative and regenerative processes: unfailing faith that there is a treasure, if you can only find it, in the heart of every man. These are the symbols, which, in the treatment of crime and criminal, mark and measure the stored-up strength of a nation, and are sign and proof of the living virtue within it. (col. 1354)

Surely no contemporary Home Secretary would pen such a speech without giving parallel attention to the needs of the victim. The victim is invisible in the Churchill speech. Zedner (1997) identifies the establishment of the Criminal Injuries Compensation Board in 1964 and the beginnings of Victim Support in Bristol in 1974 as key events in the victim movement in the UK, and charts its dramatic growth since then. The important question concerns what the probation service would have looked like had the victim movement been active at its inception. If the need for help had not been seen to begin and end with the person in the dock, what would the service have done? It would have ministered to all those caught up in and hurt by criminal justice process, rather than merely those punished by it. Victim support and witness protection would have been part of a generic service available to all those at need. The separate existence of an organisation such as Victim Support would surely have astonished and affronted the police court missionary. If the cab rank was fair game, why not the witness stand?

The counter-argument is that the mission involved bringing sinners to repentance, and victims weren't sinners, or at least no more than the rest of us. But does the cab stand host a bigger population of sinners than the witness box? Does not the experience of crime victimisation lead to hatreds which separate one from God? The aspiration that took the missionary to the cab stand should not have kept him from the witness box.

There are reasons why the victim movement came after the push to rehabilitate offenders (Christie 1977). When the State takes responsibility in 
criminal law, the victim is almost automatically sidelined. It's interesting to contrast this situation with the prescriptions of Judaism, and even with the Islamic law of Shia, as has recently been done by Saffary (1998). It is beyond doubt that shia law never separated victim concerns and offender punishment. If criminal law had never developed as it did, the probation service would certainly not have been limited in the way it was. The question remains as to whether it is now too late to re-invent the probation service as a generic helping service for the courts. Doing so would present formidable difficulties (see for example Brownlee 1998). The notion of altruism is passe in the service. As Mike Nellis (personal communication) opines: 'Altruism has not figured on lists of social work values for twenty years, perhaps more ... altruism is for amateurs, not professionals'. Yet to revive probation as a service which gives help where there is a need for help to alleviate the secondary victimisation which criminal justice entails, would chime precisely with the impulses and practice of the police court missionary. That the police court missionary did not specifically minister to victims is surely just an accident of history. That other views had prevailed under secular probation is clear. Mike Nellis (personal communication) writes: 'it has always struck me as odd that probation officers I met in the early 1980 s were so reluctant to take victim issues on board'. This corresponds with my experience. I felt that the adversarial structure of criminal law saw taking sides as the first first step for the probation officer. Of course, some leaders of the probation service even then (for example, Harding 1982) had incorporated victim concerns in their thinking.

\section{Stand Up, Al Truism}

The point has arrived at which to explain the title of this paper more fully. The first reason is that Bill McWilliams would have liked it. The second is that altruism has two kinds of career in probation. The first is the individual altruism of officers joining the service. Bill never wavered in his view that the motives of new officers were noble, and that their central motive was the selfless provision of help. However, personal altruism survives intact only in organisations conducive to it, and I think Bill saw the career trajectory of probation officers' altruism as being the manifest justification for their work as being too short, being replaced by cynicism and the politicking to which frustrated idealists are prone. The second altruism career is that of the service as a whole. In its first manifestation, imperfect as it was, the tone of the service was moral. Its later manifestations were not overtly moral. The consequence was the career trajectory for individual officers described above. Bill's attempt was to reintroduce a central moral justification for the service. That can most readily be done by transforming the probation service into a generic helping service for all those whose experience of criminal justice impoverishes them, materially, emotionally or spiritually. It would de-emphasise and become honest about the cost in crime which such an approach incurs, and seek over time to lessen that cost, without justification by partial data compiled using odd conventions. The pity is that Bill McWilliams will not be here to argue the case. 


\section{Notes}

1 This paper is a modified version of a lecture presented as the first Bill McWilliams Memorial Lecture at De Montfort University, Leicester, on 1 July 1998. I am grateful to those at the lecture who made comments, and especially to Dr Mike Nellis, whose later comments were invaluable. The lecture required a re-reading of the entire Bill McWilliams opus, which make it clear that his perspective on probation practice remains invaluable. Special thanks are due to Brenda McWilliams, whose presence provided the foundation necessary for Bill's work, the selfless support in his final illness, and inspiration to the rest of us.

2 For purposes of simplicity, remission is ignored.

3 Figure 1 shows cumulative percentage reconvictions for custody and community penalties, assuming all prisoners spend seven months in custody (the real figure is 0.562 years on the latest figures given by Tarling 1993), and assuming the distribution of times at risk to reconviction given for parolees by Tarling (1993), and the proportion reconvicted after two years at risk as $50 \%$, being close to the overall figure calculated by Lloyd et al. (1994).

4 In the week when this paper was revised, a report of the Home Affairs Select Committee on Alternatives to Imprisonment (HOC 486-11) provides a perfect instance of political cynicism, ignorance or the preference of short-run financial considerations over a willingness to tackle these issues.

5 Mike Nellis (personal communication): 'Bill did not write as one of history's victors. It was a sideways view rather than an underdog'. I agree that Bill never felt wholly vanquished.

6 Mike Nellis (personal communication) believes that Bill's acceptance of punishment as a penal (and probation) purpose is not generally recognised.

7 This debate must be conducted in relation to school truancy, where received wisdom appears to be that exclusion from school causes delinquency, rather than reflects it.

\section{References}

Adamson, J. (1997) 'England without Cromwell', in: N. Ferguson (Ed.), Virtual History: Alternatives and Counterfactuals, London: Picador.

A Middlesex Magistrate (1911) The Justice of the Peace and his Functions on and off the Bench, London: Dent.

Blumstein, A. et al. (1986) Criminal Careers and Career Criminals, Washington, DC: National Academy Press.

Bochel, D. (1976) Probation and After-Care, Edinburgh: Scottish Academic Press.

Bottoms, A.E. (1977) 'Probation's past', Times Higher Education Supplement, 16 May, 19.

Bottoms, A.E. and McWilliams, W.W. (1979) 'A non-treatment paradigm for probation practice', British Journal of Social Work, 9, 159-202.

Brownlee, I. (1998) Community Penalties, London: Longman.

Carr, E.H. (1987) What Is History?, 2nd ed., London: Allen and Unwin.

Cheetham, J. (1998) 'Crime, probation and social work: enduring rights and wrongs', in: D. Faulkner and A. Gibbs (Eds.), New Politics, New Probation?, Oxford: University of Oxford Centre for Criminological Research.

Christie, N. (1977) 'Conflicts as property', British Journal of Criminology, 17, 1-15.

Collins, P. (1994) Dickens and Crime, 3rd ed., Basingstoke: Macmillan.

Duff, A. (1986) Trials and Punishments, Cambridge: Cambridge University Press.

Duffy, K. (1998) 'Combating social exclusion and promoting social integration in the European Union', in: C. Oppenheim (Ed.), An Inclusive Society, London: IPPR. 
Ferguson, N. (Ed.) (1997) Virtual History: Alternatives and Counterfactuals, London: Picador.

Gewirth, A. (1978) Reason and Morality, Chicago: University of Chicago Press.

Harding, J. (1982) Victims and Offenders, London: Bedford Square Press.

Hedderman, C., Sugg, D. and Vennard, J. (1997) Changing Offenders' Attitudes and Behaviour: What Works? (Home Office Research Study No. 171), London: HMSO.

Holmes, T. (1908) Known to the Police, London: Nelson.

Home Office (1922a) Report of the Departmental Committee on the Training, Appointment and Payment of Probation Officers, Cmnd. 1601.

Home Office (1922b) Report of the Departmental Committee on the Treatment of Young Offenders, Cmnd. 2831.

Home Office (1936) Report of the Departmental Committee on the Social Services in Courts of Summary Jurisdiction, Cmd. 5122.

King, J.F.S. (1958) The Probation Service, London: Butterworth.

Kunz, D. (1997) 'Camelot continued', in: N. Ferguson (Ed.), Virtual History: Alternatives and Counterfactuals, London: Picador.

Lloyd, C., Mair, G. and Hough, M. (1994) Explaining Reconviction Rates: A Critical Analysis (Home Office Research Study No. 136), London: HMSO.

McGuire, J. (1995) What Works: Reducing Reoffending, Chichester: Wiley.

McWilliams, W.W. (1981) 'The probation officer at court: from friend to acquaintance', Howard Journal, 20, 97-116.

McWilliams, W. (1983) 'The mission to the English police courts 1876-1936', Howard Journal, 22, 129-47.

McWilliams, W.W. (1985) 'The mission transformed: professionalisation of probation between the wars', Howard Journal, 24, 257-74.

McWilliams, W.W. (1986) 'The English probation system and the diagnostic ideal', Howard Journal, 25, 241-60.

McWilliams, W.W. (1987) 'Probation, pragmatism and policy', Howard Journal, 26, 97-121.

McWilliams, W.W. and Pease, K. (1990) 'Probation practice and an end to punishment', Howard Journal, 29, 14-24.

Nellis, M. (1997) 'Bill McWilliams 1932-1997', Howard Journal, 36, 225-6.

Parliamentary Debates (1910) House of Commons XIX, col. 1354.

Pease, K. (1994) 'Cross-national imprisonment rates: limitations of method and possible conclusions', in R.D. King and M. Maguire (Eds.), Prisons in Context, Oxford: Oxford University Press.

Pease, K. and McWilliams, W.W. (1976) Community Service by Order, Edinburgh: Scottish Academic Press.

Saffary, A. (1998) 'Shia law and western criminal justice' (unpublished PhD thesis, University of Leicester).

Tarling, R. (1993) Analysing Offending, London: HMSO.

Thompson, A.C. (1884) 'Monday morning in the police court', Church of England Temperance Chronicle, 12, 291.

Wright, M. (1982) Making Good, London: Burnett Books.

Zedner, L. (1997) 'Victims', in M. Maguire et al. (Eds.), Oxford Handbook of Criminology, 2nd ed., Oxford: Clarendon Press.

Date submitted: July 98

Date accepted: August 98 